\title{
EFEKTIVITAS BAHAN INSTRUKSIONAL PENDIDIKAN AGAMA ISLAM
}

\author{
Suradika $^{1)}$, Widia Winata ${ }^{2}$, Dirgantara Wicaksono ${ }^{3)}$, Rifqiyati ${ }^{4)}$ \\ ${ }^{1}$ Magister Teknologi Pendidikan, Universitas Muhammadiyah Jakarta \\ email: agus.suradika@umj.ac.id \\ ${ }^{2}$ Magister Teknologi Pendidikan, Universitas Muhammadiyah Jakarta \\ email: widia.winata@umj.ac.id \\ ${ }^{3}$ Magister Teknologi Pendidikan, Universitas Muhammadiyah Jakarta \\ email: dirgantarawicaksono@umj.ac.id \\ ${ }^{4}$ Fakultas Ilmu Sosial dan Ilmu Politik, Universitas Muhammadiyah Jakarta \\ email: rifqiyati@umj.ac.id
}

\begin{abstract}
The aim of this research is to determine the effect of instructional material on the echievement in Islamic Education. The experiment was conducted at the Faculty of Social and Political Sciences, the University of Muhammadiyah Jakarta, during the second semester of the academic year 2018/2019, using "The twogroups posttest-only randomized experiment". A sample of 60 students was ramdomly choosen from the available students, i.e. 30 students for individualized instructional material, and 30 students others for the $P B S$ one. The result of hyphotheses testing showed that Individualized instructional material $(\bar{x}=81,37)$ resulted in a better achievement than the PBS one $(\bar{x}=77,39)$
\end{abstract}

Keywords: instructional material, individualized instructional material, PBS material, learning outcome, Islamic education.

\begin{abstract}
Abstrak
Tujuan penelitian ini adalah untuk mengetahui pengaruh bahan instruksional terhadap hasil belajar Pendidikan Agama Islam. Eksperimen dilakukan di Fakultas Ilmu Sosial dan Ilmu Politik, Universitas Muhammadiyah Jakarta selama semester genap tahun akademik 2018/2019. Penelitian ini menggunakan eksperimen acak dengan dua kelompok mahasiswa. Sampel sebanyak 60 mahasiswa yang dipilih secara random yaitu 30 mahasiswa untuk bahan instruksional Mandiri dan 30 mahasiswa untuk PBS. Hasil pengujian hipotesis menunjukkan bahwa bahan instruksional Mandiri sebesar $(\bar{x}=81,37)$ menunjukkan hasil belajar yang lebih baik dibandingkan PBS yakni sebesar $(\bar{x}=77,39)$.
\end{abstract}

Kata kunci: bahan instruksional, bahan instruksional Mandiri, bahan instruksional PBS, hasil belajar, Pendidikan Agama Islam.

\section{PENDAHULUAN}

Masyarakat Indonesia dikenal sangat religius. Dalam Undang-undang nomor 20 tahun 2003 tentang Sistem Pendidikan Nasional, secara jelas dinyatakan bahwa Pendidikan Agama adalah salah satu komponen kurikulum yang wajib diberikan kepada peserta didik di setiap jenis, jalur, dan jenjang pendidikan. Sejalan dengan pemikiran Harun Nasution (Nasution, 1995: 15) dan Riberu (Riberu, 1995: 41), pendidikan agama harus mampu mendorong peserta didik untuk menerapkan ajaran agama yang sudah dihayati dan menjelma dalam perilaku sehari-hari. Oleh karenanya dalam mentransformasikan pengetahuan keagamaan, tenaga pendidik tidak boleh mengabaikan falsafah moral yang menjadi dasar semuanya.

Usaha untuk mencapai tujuan tersebut telah dilaksanakan dengan sungguhsungguh, tetapi hasilnya belum sesuai dengan yang diharapkan. Penelitian yang dilaksanakan oleh Rifqiyati dkk (Rifqiyati, 1994: 27-31) menyimpulkan dua hal yaitu (a) bagaimanapun hasil belajar pendidikan agama mahasiswa tidak memberikan perbedaan perilaku keagamaan mereka, dan 
(b) apapun sikap mahasiswa terhadap peraturan ternyata juga tidak memberi perbedaan perilaku keagamaan mereka. Dari temuan ini dapat dikemukakan bahwa pengetahuan yang diperoleh mahasiswa dari pendidikan agama belum dapat mendorong mereka untuk menerapkannya dalam kehidupan sehari-hari. Keadaan sebagaimana tersebut di atas perlu mendapat perhatian.

Untuk menjawab persoalan ini, Suradika dan Sri Mulyani (Suradika, dkk, 1997: 3-4) melakukan penelitian kualitatif. Dari penelitian tersebut diketahui bahwa belum sistematisnya metode pembelajaran dan belum memadainya bahan pembelajaran merupakan dua faktor yang menyebabkannya. Bahan lnstruksional yang digunakan selama ini terbatas pada bukubuku teks yang ada.

Dari latar belakang ini, timbul pertanyaan-pertanyaan sebagai berikut: bagaimana meningkatkan pengetahuan Agama Islam mahasiswa sehingga mereka dapat mencapai tujuan pendidikan yang ditentukan? Faktor-faktor apakah sebenarnya yang menyebabkan mahasiswa tidak dapat meningkatkan pengetahuan agamanya sehingga mereka belum dapat menerapkan dalam kehidupan sehari-hari? Apakah karena mahasiswa jenuh dengan ceramahceramah agama dan mereka tidak dapat memperoleh suri tauladan di masyarakat? Ataukah karena pendekatan mengajar yang dipakai dosen selama ini salah? Bagaimana dapat meningkatkan motivasi dan minat mahasiswa untuk belajar agama yang memang diperlukan? Apakah dengan mengembangkan bahan instruksional yang ada di lapangan, hasil belajar pendidikan agama akan dapat meningkat? Apakah bahan instruksional yang selama ini digunakan mengacu pada silabus dan SAP yang ada dan dapat dipahami dengan mudah oleh mahasiswa? Apakah untuk belajar Mata Kuliah Pendidikan Agama Islam di perguruan tinggi, latar belakang pendidikan merupakan faktor yang mempengaruhi? Apakah faktor dosen mempengaruhi hasil belajar pendidikan agama? Apakah dosen telah berusaha semaksimal mungkin untuk meningkatkan hasil belajar mahasiswa dalam pendidikan agama? Masalah-masalah tersebut merupakan pertanyaan yang patut diketahui jawabannya untuk meningkatkan hasil belajar Pendidikan Agama Islam mahasiswa di Perguruan Tinggi Umum.

Mengingat luasnya permasalahan yang teridentifikasi, maka di dalam penelitian ini masalah dibatasi pada pemanfaatan bahan instruksional dalam bentuk (a) Mandiri dan (b) Pengajar-Bahan-Siswa atau disingkat PBS dalam pembelajaran Pendidikan Agama Islam. Rumusan masalah penelitian sebagai berikut: "Apakah ada pengaruh bahan instruksional terhadap hasil belajar pendidikan agama Islam? Jika ada, bahan instruksional manakah yang akan memberikan hasil belajar pendidikan Agama Islam lebih tinggi, bahan instruksional Mandiri atau PBS?

\section{KAJIAN LITERATUR \\ Bahan Instruksional}

Bahan instruksional mempunyai kaitan yang sangat erat dengan sistem instruksional. Pembahasan mengenai pengembangan suatu bahan instruksional harus juga membahas secara tuntas sistem instruksional yang mendasarinya. Gagne et al mendefinisikan sistem instruksional sebagai "an Instructional system may be defined as an arrangement of resources and procedures used to facilitate learning" (Gagne et al, 2005: 18). Dikatakan bahwa sistem instruksional berkaitan dengan pengaturan sumber daya dan prosedur untuk memfasilitasi pembelajaran.

Sejalan dengan pendapat Gagne, Smaldino et al (2005: 25) mendefinisikan "an instructional systems consist of a set of interrelated components that work together, 
effectivelly and reliably, within a particular framework to provide learning activities necessary to accomplish a learning goal. (Smaldino et al, 2005: 25) " Dalam sebuah sistem pembelajaran, didalamnya memuat komponen-komponen yang saling tergantung satu sama lain yang bekerja bersama dalam memfasilitasi kegiatan pembelajaran yang dibutuhkan untuk mencapai tujuan pembelajaran. Berdasarkan dua definisi tersebut dapat ditarik suatu kesimpulan bahwa sistem pembelajaran merupakan "kumpulan unsur-unsur yang berinteraksi dan saling bergantung satu sama lain dalam usaha memfasilitasi pembelajaran untuk mencapai tujuan pembelajaran".

Di dalam literatur ditemukan sejumlah model pengembangan sistem instruksional, salah satunya adalah model Dick dan Carey. Dalam siklus yang dibuat oleh Dick dan Carey tahap pengembangan bahan instruksional dirancang setelah ditetapkannya strategi instruksional (Dick dan Carey, 2009: 136, 168). Strategi instruksional menjelaskan komponenkomponen dari suatu set bahan instruksional dan prosedur yang akan digunakan bersama bahan-bahan tersebut untuk mencapai hasil belajar tertentu. Lima komponen strategi instruksional adalah (a) kegiatan prainstruksional, (b) penyajian informasi, (c) partisipasi siswa, (d) tes, dan (e) tindak lanjut. Strategi instruksional digunakan untuk menilai apakah bahan yang dikembangkan atau yang tersedia sudah memenuhi syarat atau masih perlu disesuaikan sebelum digunakan. Penilaian bahan dilakukan guna menentukan apakah bahan (a) cukup menarik, (b) sesuai isinya, (c) tepat urutannya, (d) mempunyai informasi yang dibutuhkan, (e) memiliki soal latihan, (f) terdapat jawaban latihan yang jelas untuk usaha-usaha perbaikan, dan (g) terdapat petunjuk bagi siswa yang mengarahkan mereka dari satu kegiatan ke kegiatan belajar lainnya.
Pengembangan bahan instruksional merupakan sub-sistem dari pengembangan sistem instruksional. Suparman membedakan tiga bentuk pengembangan bahan instruksional berdasarkan bentuk kegiatan instruksional, yaitu untuk (a) pembelajaran mandiri, di mana pengajar bertindak sebagai fasilitator dan siswa belajar mandiri, dilakukan pengembangan bahan instruksional mandiri, (b) pembelajaran konvensional, di mana pengajar sebagai sumber tunggal dan siswa belajar darinya, dikembangkan bahan instruksional konvensional, dan (c) pembelajaran PBS (Pengajar-Bahan-Siswa) di mana pengajar bertindak sebagai penyaji bahan belajar yang dipilihnya, dikembangkan bahan instruksional PBS (Suparman, 2012: 200). Berikut ini akan dikemukakan dua bentuk bahan instruksional yang digunakan dalam penelitian ini, yaitu bahan instruksional (a) Mandiri, dan (b) PBS.

\section{Bahan Instruksional Mandiri}

Bahan instruksional Mandiri dirancang secara khusus untuk belajar mandiri. Peran pengajar dalam pembelajaran ini adalah sebagai fasilitator yang diharapkan dapat membantu siswa agar lebih mudah mempelajari bahan tersebut, mengontrol kemajuan siswa, memberi motivasi dan petunjuk, membantu kesulitan yang dihadapi siswa, dan menyelenggarakan tes. Jenis bahan yang digunakan bisa salah satu atau kombinasi dari beberapa program media, antara lain bahan cetak, film, kaset, audio, program radio, program video, televisi, computer, dan sebagainya.

Bahan instruksional Mandiri mempunyai kelebihan dan kekurangan. Dari beberapa literatur, dapat dikemukakan beberapa kelebihan dan kekurangan bahan instruksional mandiri yang berkaitan dengan keefektifan belajar. Kelebihannya adalah pertama, bahan instruksional Mandiri dapat 
memberikan kesempatan kepada mahasiswa untuk belajar menurut kecepatannya masingmasing. Hal ini dimungkinkan karena dalam bahan tersebut terdapat petunjuk bagi mahasiswa kapan ia harus maju untuk mempelajari topik pelajaran berikutnya, kapan ia harus mengulang untuk mempelajari topik yang sama atau topik yang lain. Mereka yang cepat kemampuan belajarnya dapat terus maju tanpa terganggu oleh mereka yang lambat. Sebaliknya mereka yang lambat tidak perlu merasa tertinggal oleh mereka yang cepat (Romiszowski, 1981: 358), (Kemp, 1977: 55), (Dick dan Carey, 2009:166-167), (Suparman, 2012: 197-200).

Kedua, dalam bahan instruksional Mandiri mahasiswa dapat memperoleh umpan balik yang dapat digunakan sendiri. Pentingnya pemberian umpan balik di dalam proses pembelajaran dikemukakan oleh Gagne, menurutnya, umpan balik dibutuhkan dalam pembelajaran agar si pembelajar dapat mengetahui apakah unjuk kerja (performance) yang mencerminkan kapabilitas yang baru dipelajarinya itu benar atau salah (Gagne, 2005: 315). Dengan adanya umpan balik pada bahan instruksional Mandiri yang dapat digunakan sendiri oleh mahasiswa diharapkan mereka dapat segera mengetahui sudah sampai di mana tingkat penguasaannya mengenai suatu topik bahasan.

Di samping memiliki kelebihan, bahan instruksional Mandiri juga mempunyai kelemahan, yaitu pertama, menuntut disiplin belajar mahasiswa yang tinggi. Tanpa disiplin belajar yang tinggi, sebaik apapun kualitas suatu bahan instruksional Mandiri tidak akan ada gunanya. Dengan kata lain dapat dikemukakan bahwa selain kualitas bahan pembelajaran, disiplin belajar merupakan faktor yang sangat menentukan keberhasilan belajar siswa. Kedua, proses pembelajaran dengan menggunakan bahan pembelajaran Mandiri menuntut ketekunan pengajar/fasilitator untuk memantau keberhasilan mahasiswa, memotivasi, dan memberi konsultasi bagi yang membutuhkan.

\section{Bahan Instruksional PBS}

Bahan instruksional Pengajar-BahanSiswa (PBS) merupakan bahan yang dikompilasi dari bahan belajar yang ada. Oleh karena tidak dimaksudkan sebagai bahan belajar mandiri, tentu saja penggunaan bahan sangat membutuhkan adanya tenaga pengajar. Suparman mengemukakan bahwa tulang punggung penggunaan bahan instruksional PBS bersumber pada bahan instruksional dan pengajar, keduanya harus saling mengisi. Sesuatu yang tidak terdapat pada bahan instruksional PBS dilengkapi oleh pengajar (Suparman, 2012: 197).

Seperti halnya bahan instruksional Mandiri, bahan PBS juga mempunyai kelebihan dan kekurangan. Kelebihan bahan ini terletak pada kelenturannya, yaitu mudahnya menyesuaikan kegiatan instruksional dengan keadaan mahasiswa atau perubahan-perubahan yang berkaitan dengan isi suatu mata pelajaran. Kekurangannya terletak pada pemilihan bahan yang ada di perpustakaan yang belum tentu sesuai benar dengan yang dibutuhkan mahasiswa. Ketidaksesuaian tersebut dapat terletak pada isi maupun urutan penyajiannya serta kedalaman isi yang mungkin lebih dari apa yang dibutuhkan atau sebaliknya. Untuk mengatasi masalah ini biasanya pengembang bahan kemudian mengambil berbagai sumber agar saling mengisi. Namun demikian cara inipun masih mengandung kelemahan utama yang berhubungan dengan konsistensi dan keterkaitan antara berbagai sumber tersebut.

\section{Hasil Belajar Pendidikan Agama Islam}

Ragam kapabilitas yang ingin dicapai dalam pendidikan agama adalah tidak hanya 
penguasaan tentang pengetahuan pendidikan agama tetapi juga yang berkaitan dengan sikap dan perilaku. Sikap memberikan disposisi atau kesiapan untuk melakukan tindakan tertentu (Gagne, 2005: 223). Sikap pada umumnya dipandang memiliki komponen afektif (emosi), segi kognitif, dan konsekuensi tingkah laku (Gagne, 2005:230235). Sikap dipelajari dengan berbagai cara, tiga di antaranya adalah melalui (a) pengalaman tunggal, seperti seorang yang takut pada ular karena ia mempunyai pengalaman yang menakutkan yang berhubungan dengan ular semasa kecil, (b) pengalaman sukses dan rasa senang seseorang, seperti seorang anak yang merasa senang karena sukses memainkan video gamenya, dan (c) meniru orang lain, seperti seorang anak yang belajar bagaimana menghadapi orang yang belum dikenal dengan jalan melihat apa yang dilakukan oleh orang tuanya.

Lambert mengemukakan bahwa "learning is a constructive process that occurs best when the learner is actively engaged in creating her or his own knowledge and understanding by connecting what is being learned with prior knowledge and experience" (Lambert and McCombs dalam Watkins, 2007: 72). Dikatakan bahwa belajar merupakan proses konstruktif yang terjadi ketika peserta didik secara aktif terlibat dalam menciptakan pengetahuan dan pemahamannya sendiri dengan menghubungkan apa yang sedang dipelajari dengan pengetahuan dan pengalaman sebelumnya yang sudah dimiliki.

Selanjutnya Mayer mengemukakan bahwa "Learning is the relatively permanent change in a person's knowledge or behavior due to experience. This definition has three components; 1) the duration of the change is long-term rather than short-term; 2) the locus of the change is the content and structure od knowledge in memory or the behavior of the learner; 3) the cause of the change is the learner's experience in the environment rather than fatique, motivation, drugs, physical condition, or psychological intervention" (Mayer dalam Richey, Klein dan Tracey, 2011:51).

Mengacu pada beberapa pandangan dan uraian tersebut di atas, dapat disimpulkan bahwa belajar adalah semua hal yang berhubungan dengan perubahan perilaku manusia yang diperoleh dari pengalaman dalam berbagai bentuk, baik berupa pengetahuan, keterampilan dan sikap yang terukur. Perubahan perilaku yang terukur itulah yang disebut sebagai hasil belajar.

Slavin mengatakan bahwa hasil belajar (learning outcomes) adalah "learning outcomes are commonly expressed in terms of competences or skills and competences, competences are understood as a combination of attributes (as regards knowledge and its application to attitudes, skills and responsibilities) that describe the level or degree to which a person is capable of performing a given task" (Slavin dalam Barsky, 2008:8). Dikatakan bahwa hasil belajar umumnya dinyatakan dalam bentuk keterampilan dan kompetensi, di mana kompetensi merupakan kombinasi atribut (berupa pengetahuan, sikap, keterampilan dan tanggung jawab) yang menggambarkan tingkat atau derajat di mana seseorang mampu melakukan tugas yang diberikan. Selanjutnya Krathwohl membagi hasil belajar dalam tiga kawasan yaitu kognitif, afektif, dan psikomotor (Krathwohl dalam Molenda, 2008: 51).

Berdasarkan uraian-uraian tersebut dapat dikemukakan bahwa hasil belajar terjadi apabila kegiatan belajar disertai oleh adanya perubahan baik di ranah kognitif, afektif, maupun psikomotorik. Hasil belajar seseorang pada umumnya dapat diukur melalui beberapa alat, yaitu (a) tes untuk ranah kognitif, (b) skala sikap untuk ranah afektif, dan daftar cek untuk ranah psikomotorik. Keseluruhan alat ukur tersebut 
dirancang berdasarkan tujuan instruksional khusus yang telah ditetapkan. Dengan demikian dapat dikemukakan bahwa indikator dari hasil belajar pendidikan Agama Islam adalah perolehan skor dari keseluruhan alat ukur yang digunakan yang dirancang berdasarkan tujuan instruksional khusus. Berdasarkan kajian literatur sebagaimana telah dikemukakan di atas dapat dikemukakan kerangka berfikir sebagai berikut: bahan instruksional di dalam proses pembelajaran merupakan faktor yang sangat penting. Melalui bahan tersebut pembelajaran diarahkan untuk mencapai tujuan tertentu. Bahan instruksional Mandiri berbeda dengan bahan instruksional PBS. Perbedaan-perbedaan tersebut terletak pada beberapa aspek seperti tampak pada tabel berikut ini:

Tabel 1.

\section{Perbedaan Bahan Instruksional Mandiri dan PBS}

\begin{tabular}{|c|c|c|}
\hline Aspek & Mandiri & PBS \\
\hline $\begin{array}{l}\text { Bentuk } \\
\text { Bahan } \\
\text { Instruksional }\end{array}$ & $\begin{array}{l}\text { Dipilih dan ditulis } \\
\text { kembali oleh } \\
\text { Pengembang }\end{array}$ & $\begin{array}{l}\text { Dipilih dari bahan } \\
\text { yang ada }\end{array}$ \\
\hline Umpan balik & $\begin{array}{l}\text { Dapat diperoleh } \\
\text { langsung dari } \\
\text { bahan, digunakan } \\
\text { secara teratur }\end{array}$ & $\begin{array}{l}\text { Tidak selalu } \\
\text { langsung dari } \\
\text { bahan, banyak } \\
\text { dari pengajar }\end{array}$ \\
\hline $\begin{array}{l}\text { Waktu yang } \\
\text { digunakan } \\
\text { pengajar }\end{array}$ & $\begin{array}{l}\text { Banyak } \\
\text { kesempatan untuk } \\
\text { memantau dan } \\
\text { memotivasi } \\
\text { mahasiswa, } \\
\text { karena selain dari } \\
\text { dosen, mahasiswa } \\
\text { belajar mandiri }\end{array}$ & $\begin{array}{l}\text { Banyak digunakan } \\
\text { untuk menyajikan } \\
\text { isi pelajaran. } \\
\text { Kegiatan terhenti } \\
\text { saat pengajar } \\
\text { menjawab } \\
\text { pertanyaan } \\
\text { mahasiswa }\end{array}$ \\
\hline $\begin{array}{l}\text { Disiplin } \\
\text { mahasiswa }\end{array}$ & Harus tinggi & $\begin{array}{l}\text { Bila rendah, } \\
\text { pengajar dapat } \\
\text { memotivasi }\end{array}$ \\
\hline $\begin{array}{l}\text { Tujuan } \\
\text { Instruksional }\end{array}$ & $\begin{array}{l}\text { Secara tegas } \\
\text { disebutkan }\end{array}$ & $\begin{array}{l}\text { Sebagian besar } \\
\text { tidak } \\
\text { menyebutkan }\end{array}$ \\
\hline $\begin{array}{l}\text { Keterlibatan } \\
\text { mahasiswa } \\
\text { ketika mem } \\
\text { baca buku }\end{array}$ & Dilibatkan & $\begin{array}{l}\text { Sebagian besar } \\
\text { tidak melibatkan } \\
\text { mahasiswa }\end{array}$ \\
\hline $\begin{array}{l}\text { Sistematika } \\
\text { bahan }\end{array}$ & Sistematis & $\begin{array}{l}\text { Lebih banyak } \\
\text { melompat dari } \\
\text { satu pokok ke } \\
\text { pokok bahasan } \\
\text { lainnya }\end{array}$ \\
\hline $\begin{array}{l}\text { Tingkat } \\
\text { keterbacaan }\end{array}$ & $\begin{array}{l}\text { Mudah dipahami, } \\
\text { sesuai dengan } \\
\text { karakteristik } \\
\text { mahasiswa }\end{array}$ & $\begin{array}{l}\text { Sebagian besar } \\
\text { sukar dipahami }\end{array}$ \\
\hline
\end{tabular}

Berdasarkan tabel 1 tersebut dapat diduga bahwa pembelajaran yang menggunakan bahan instruksional Mandiri akan memberikan hasil belajar Pendidikan Agama Islam yang berbeda dibandingkan dengan pembelajaran yang menggunakan bahan instruksional PBS. Hal itu karena beberapa sebab.

Pertama, pada pembelajaran dengan bahan instruksional Mandiri, peran pengajar lebih banyak digunakan untuk memantau kemajuan mahasiswa dan memotivasi mereka. Di samping itu, belajar tetap dapat dilakukan oleh mahasiswa kendatipun tanpa kehadiran pengajar. Kedua, bahan instruksional yang digunakan dalam pembelajaran mandiri dirancang khusus dengan memperhatikan karakteristik umum dari mahasiswa. Hal ini memungkinkan diberikannya contoh-contoh yang relevan dan mudah dipahami oleh mahasiswa. Selanjutnya bahan instruksional PBS mengggunakan bahan yang dipilih dari perpustakaan sehingga sangat memungkinkan terjadi ketidaksesuaian uraian, contoh, atau latihan dengan karakteristik umum dari mahasiswa.

Ketiga, satu masalah penting dalam belajar adalah umpan balik. Mahasiswa perlu dengan segera mengetahui apakah sesuatu yang dipelajarinya itu telah benar. Dalam bahan instruksional Mandiri, mahasiswa dapat menggunakan umpan balik yang ada pada bahan instruksional yang digunakan. Sementara dalam bahan instruksional PBS, umpan balik biasanya diberikan oleh pengajar melalui tugas-tugas terstruktur. Jadi, sangat tergantung pada pengajar. Keempat, dengan menyebutkan secara tegas tujuan instruksional khusus yang akan dicapai, mahasiswa dapat mengetahui ke arah mana ia akan "dibawa" dalam proses belajar tersebut. Hal ini akan memotivasi mereka di dalam mempelajari bahan instruksional Mandiri. 
Kelima, dalam bahan instruksional Mandiri, digunakan kalimat yang mengajak mahasiswa untuk memecahkan masalah, mencoba sesuatu, dan menemukan sesuatu. Hal ini menyebabkan mahasiswa merasa terlibat ketika membaca, sesuatu yang jarang ditemukan dalam buku teks. Keenam, hal lain yang penting dalam belajar adalah mempelajari sesuatu secara sistimatis dari yang mudah ke yang sulit. Hal ini berkaitan dengan penyajian pokok bahasan. Dalam bahan belajar Mandiri pokok bahasan disajikan secara sistematis dari yang mudah ke yang sulit, sedangkan dalam menggunakan buku teks tidak jarang harus melompat dari satu bab ke bab lainnya.

Terakhir, Ketujuh, penggunaan kalimat yang dirancang sesuai karakteristik umum mahasiswa dalam bahan instruksional Mandiri memudahkan mereka untuk memahami isi bahan tersebut. Berdasarkan argumentasi ini maka dapat diduga pembelajaran yang menggunakan bahan instruksional Mandiri akan memberikan hasil belajar Pendidikan Agama Islam yang lebih baik dibandingkan dengan pembelajaran yang menggunakan bahan instruksional PBS. Atau dengan kata lain dapat dikemukakan bahwa bahan instruksional Mandiri lebih efektif dibandingkan dengan bahan instruksional PBS.

Berdasarkan kerangka berfikir sebagaimana telah dikemukakan di atas, maka dapat dirumuskan hipotesis: "Bahan Instruksional Mandiri akan memberikan hasil belajar Pendidikan Agama Islam lebih tinggi dibandingkan dengan Bahan instruksional PBS"

\section{METODE PENELITIAN}

Penelitian ini dilaksanakan di Fakultas Ilmu Sosial dan Ilmu Politik, Universitas Muhammadiyah Jakarta. Penelitian dilaksanakan pada semester genap tahun akademik 2018/2019 yaitu pada bulan
Februari s/d Juli 2019. Pelaksanaan diberikan selama 16 kali pertemuan termasuk tes pertengahan semester dan tes akhir semester.

Populasi penelitian ini adalah mahasiswa Fakultas Ilmu Sosial dan Ilmu Politik Universitas Muhammadiyah Jakarta yang mengikuti kuliah Al Islam II pada semester genap tahun akademik 2018/2019. Sampel sebanyak 60 orang mahasiswa diambil dari dua kelas dengan cara acak. Tiap kelas diambil sebanyak 30 orang, yaitu yang mengikuti pembelajaran dengan bahan instruksional Mandiri dan PBS.

Penelitian ini merupakan penelitian eksperimental yang dilakukan dengan menggunakan rancangan "The two-group posttest-only randomized experiment". Rancangan ini dipandang sebagai rancangan yang paling sederhana dari semua desain eksperimental (Trochim, 2020). Dalam notasi desain, terdapat dua garis, satu untuk setiap kelompok, dengan $\mathrm{R}$ di awal setiap baris untuk menunjukkan bahwa kelompokkelompok tersebut ditetapkan secara acak. Satu kelompok mendapat perlakuan diberikan bahan instruksional Mandiri dan kelompok lain adalah kelompok pembanding yang diberikan dengan bahan instruksional PBS. Gambar dari desain penelitian ini sebagai berikut:

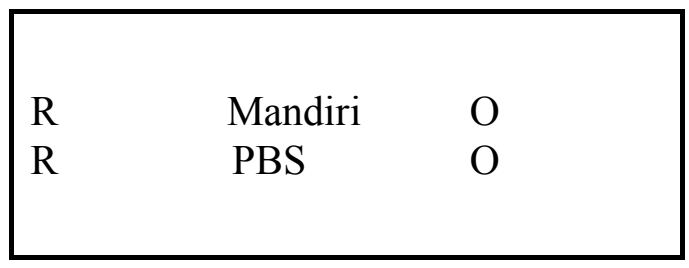

Gambar 1. Desain Penelitian

Untuk mendapat keyakinan bahwa rancangan penelitian yang dipilih cukup baik untuk menguji hipotesis penelitian dan hasilnya dapat digeneralisasikan, maka diperlukan pengontrolan validitas internal maupun ekesternal rancangan penelitian 
(Isaac and Michael, 1982: 59-63). Perlakuan yang diberikan dapat dijelaskan sebagai berikut. Kelompok mahasiswa program studi "Adm" diberi pengajaran dengan menggunakan bahan instruksional Mandiri. Selanjutnya kelompok mahasiswa program studi "kom" diberi pengajaran dengan menggunakan bahan instruksional PBS berupa (a) GBPP, (b) bahan belajar yang ada di perpustakaan, dan (c) tes.

Untuk kelompok tersebut, perkuliahan diberikan oleh dua orang dosen yang berbeda yang mempunyai kemampuan sama. Satu orang untuk kelompok Mandiri, satu orang lainnya untuk kelompok PBS. Waktu perkuliahan sama, yaitu 100 menit setiap kali pertemuan.

Penelitian ini menggunakan beberapa instrumen yaitu (a) bahan instruksional Mandiri berupa bahan belajar Al Islam II, (b) bahan instruksional PBS berupa kompilasi materi pelajaran al Islam II dari sejumlah buku yang relevan, dan (c) tes berupa tes pilihan ganda, essay, dan daftar cek. Teknik analisis data dengan uji $t$ atau ttest. Koefisien $t$ dicari dengan menggunakan aplikasi statistik yang ada, yaitu SPSS. Sebelum uji hipotesis dengan t-test, diperiksa terlebih dahulu persyaratannya, yaitu apakah (a) Skala data interval/rasio, (b) kelompok data saling bebas atau tidak berpasangan, (c) data per kelompok berdistribusi normal, (d) data per kelompok tidak terdapat outlier, (c) varians antar kelompok sama atau homogen (Hidayat, 2016).

$$
\begin{aligned}
& \text { Hipotesis statistik: } \\
& \text { Ho }: \mu \mathrm{A}=\mu \mathrm{B} \\
& \text { Ha }: \mu \mathrm{A}>\mu \mathrm{B}
\end{aligned}
$$

Pendekatan penelitian ini adalah pendekatan kuantitatif. Dipilihnya pendekatan ini karena secara epistemologi penelitian ini memadukan dua sumber ilmu, yaitu (a) pemikiran rasional, dan (b) data empiris.

\section{HASIL DAN PEMBAHASAN Deskripsi data}

Dari data yang dikumpulkan mengenai hasil belajar al-Islam II dengan menggunakan bahan instruksional Mandiri diperoleh harga rata-rata sebesar 81,37 simpangan baku 2.83. Selanjutnya hasil belajar al-Islam II dengan menggunakan bahan instruksional PBS diperoleh harga rata-rata sebesar 77.39, simpangan baku 3.04 .

\section{Pengujian Persyaratan Analisis}

a. Uji Normalitas

Hasil uji Shapiro Wilk dan Lilliefors' Nilai $p$ value (Sig) lilliefors 0,200 dan 0,150 di mana keduanya lebih besar dari 0,05 maka berdasarkan uji lilliefors, data tiap kelompok berdistribusi normal. $\mathrm{P}$ value uji Shapiro wilk pada kelompok Mandiri sebesar 0,631 > 0,05 dan pada kelompok PBS sebesar 0,076 $>0,05$. Karena keduanya $>0,05$ maka kedua kelompok sama-sama berdistribusi normal berdasarkan uji Shapiro wilk.

b. Uji tidak terdapat outlier.

Deteksi ada atau tidaknya outlier dapat menggunakan diagram stem-leaf. Ada outlier apabila terdapat nilai extrim di atas dan di bawah stem-leaf. Pada data tidak terdapat nilai ekstrim, maka tidak terdapat outlier.

c. Uji Homogenitas.

Hasil uji homogenitas dengan metode Levene's Test diperoleh nilai sebesar 0,909 dengan $\mathrm{p}$ value (sig) sebesar 0,344 , lebih besar dari 0,05. Hal ini berarti terdapat kesamaan varians antar kelompok atau yang berarti homogen.

Dengan data berskala interval, kelompok data saling bebas atau tidak berpasangan, data pada tiap kelompok berdistribusi normal, data pada tiap kelompok tidak terdapat outlier, varians antar kelompok sama atau homogen, maka persyaratan analisis dengan menggunakan t-test telah dipenuhi. 


\section{Pengujian Hipotesis}

Hasil levene test menunjukan kesamaan varians antar kelompok atau homogen. Karena homogen, maka nilai $t$ yang digunakan adalah nilai yang ada pada baris pertama yaitu nilai $t$ hitung sebesar 5,252 pada degree of fredom $(\mathrm{df})=58$. Nilai $\mathrm{p}$ value sebesar 0,000 lebih kecil dari 0,05 . Karena lebih kecil dari 0,05 maka perbedaan bermakna secara statistik atau signifikan pada probabilitas 0,05 .

Besarnya perbedaan rerata atau mean kedua kelompok ditunjukkan pada kolom Mean Difference, yaitu sebesar 3,98. Karena bernilai positif, maka berarti kelompok Mandiri memiliki nilai rata-rata lebih tinggi dari pada kelompok PBS. Hal ini berarti hipotesis yang menyatakan "Bahan Instruksional Mandiri akan memberikan hasil belajar Pendidikan Agama Islam lebih tinggi dibandingkan dengan Bahan instruksional PBS" telah dapat diuji kebenarannya dalam penelitian ini.

\section{Pembahasan Hasil Penelitian}

Hasil penelitian ini sesuai dengan pendapat Bartel yang menyatakan bahwa suatu bahan instruksional untuk suatu rencana latihan yang dikembangkan dengan baik melalui suatu pendekatan sistem akan memberi keuntungan sehingga diperoleh hasil belajar yang lebih efektif (Bartel, 1976: 21). Di samping itu sesuai juga dengan hasil penelitian Sabarti Akhadiah yang menyatakan bahwa materi paket plus lebih efektif untuk meningkatkan penelaran ilmiah dibandingkan dengan materi yang ada sebelumnya (paket) (Akhadiah, 1983: 3).

Selanjutnya penelitian ini mendukung penelitian Je Dae Sik (1996: ii-iii) yang menyatakan bahwa pengembangan materi pelajaran Bahasa Indonesia untuk para manajer Korea memerlukan perhatian pada tujuan khusus yang ingin dicapai yaitu sesuai dengan pembidangan kerja. Dalam kaitannya dengan penelitian Widodo, hasil penelitian ini makin memperkuat usulan agar penulisan buku teks perlu memperhatikan teori belajar dan prinsip-prinsip penulisan di mana perlu adanya tujuan instruksional khusus, uraian yang memadai, soal latihan, dan penjelasan materi yang masih abstrak (Widodo, 1993: 2).

\section{KESIMPULAN}

Berdasarkan hasil penelitian yang sudah dijabarkan dapat disimpulkan bahwa terdapat pengaruh bahan instruksional terhadap hasil belajar Pendidikan Agama Islam pada mahasiswa Fakultas Ilmu Sosial dan Ilmu Politik. Penggunaan bahan instruksional Mandiri lebih tinggi hasilnya dibandingkan dengan bahan instruksional PBS. Hal ini berarti hipotesis yang menyatakan "Bahan Instruksional Mandiri akan memberikan hasil belajar Pendidikan Agama Islam lebih tinggi dibandingkan dengan Bahan instruksional PBS" telah dapat diuji kebenarannya dalam penelitian ini.

Bahan instruksional merupakan variabel yang mempengaruhi hasil belajar Pendidikan Agam Islam. Tercapainya tujuan pembelajaran pada umumnya dipengaruhi oleh tiga unsur, yaitu (a) mahasiswa yang belajar, (b) dosen yang mengajar, dan (c) pengelolaan pembelajaran, termasuk di dalamnya bahan pembelajaran yang digunakan. Hasil yang diperoleh dalam penelitian ini diharapkan dapat menjadi masukan yang berguna untuk meningkatkan hasil belajar Pendidikan Agama Islam.

Hasil penelitian ini memberi petunjuk bahwa untuk memperoleh hasil belajar Pendidikan Agama Islam yang tinggi perlu dikembangkan bahan insruksional dengan memperhatikan teori dan prinsip-prinsip belajar serta mempertimbangkan karakteristik umum mahasiswa yang mengikuti perkuliahan.

Bahan instruksional Pendidikan Agama Islam yang baik seperti telah dikemukakan 
pada bagian sebelumnya adalah yang memiliki kriteria (a) memiliki daya tarik, (b) kesesuaian TIK dan TIU, (c) kesesuaian isi dan TIK, (d) kesesuaian bahasa, (e) ketepatan urutan, (f) memiliki soal latihan, (g) terdapat jawaban yang jelas untuk usahausaha perbaikan, dan (h) terdapat petunjuk bagi mahasiswa yang mengarahkan mereka dari suatu kegiatan ke kegiatan lainnya.

Daya tarik sebuah bahan instruksional yang berbentuk media cetak terletak pada penampilann fisik: artistik, ketikan yang rapi dan tidak terlalu rapat, tidak terlalu tebal, serta mudah dibawa dan dibaca. Sebuah bahan instruksional yang buruk penampilan fisiknya akan mengurangi keinginan mahasiswa untuk mempelajarinya kendatipun sesungguhnya mempunyai isi yang baik. Untuk memperoleh bahan instruksional yang memiliki daya tarik, dosen atau pengembang bahan instruksional perlu bekerja sama dengan ahli pengembang media pembelajaran.

Kesesuaian TIK dengan TIU perlu mendapat perhatian dalam pengembangan bahan instruksional. Perumusan TIK yang tidak sesuai dengan TIU akan mengakibatkan gagalnya mencapai tujuan pembelajaran karena TIK tidak diarahkan untuk mencapai TIU. Banyak kekeliruan yang dilakukan oleh dosen dalam menyusun TIK. Kekeliruan yang paling mendasar adalah ketika mereka merumuskan TIK berdasarkan isi pelajaran yang akan diajarkan. Seharusnya TIK dirumuskan sebagai penjabaran dari TIU dengan melakukan analisis instruksional agar tujuan menjadi lebih spesifik sehingga tidak mungkin ditafsirkan ke dalam pengertian lain dan menjadi lebih terukur.

Di dalam rumusan TIK terdapat unsur perilaku yang diharapkan dicapai mahasiswa pada akhir kuliah. Oleh karenanya dengan merumuskan TIK berarti telah dapat diidentifikasi isi pelajaran yang akan diajarkan. Rumusan perilaku yang ada di dalam TIK terdiri dari dua hal pokok, yaitu (a) kata kerja, dan (b) objek. Objek menunjukan topik atau pokok bahasan dari isi pelajaran. Setiap topik dapat dijabarkan menjadi beberapa sub topik.

Bahan instruksinal Mandiri dirancang dengan maksud agar mahasiswa dapat mempelajarinya sendiri tanpa banyak tergantung pada kehadiran dosen. Oleh karenanya bahasa yang digunakan haruslah bahasa yang mencerminkan pembicaraan langsung dari dosen ke mahasiswa. Dengan membaca bahan instruksional tersebut seolah-olah mahasiswa sedang berhadapan langsung dengan dosennya. Untuk itu penggunaan bahasa yang sangat formil harus dihindari, tetapi tidak berarti dalam bahan belajar tersebut digunakan bahasa percakapan sehari-hari. Dengan kata lain dapat dikemukakan bahwa bahasa yang digunakan adalah di antara bahasa formil dan bahasa sehari-hari.

Dalam menyusun urutan kegiatan instruksional terdapat dua faktor yang harus diperhatikan, yaitu (a) urutan kegiatan instruksional, dan (b) urutan penyajian yang harus disusun dari yang paling mudah ke yang paling sulit. Urutan kegiatan instruksional terdiri dari tiga komponen, yaitu (a) komponen pendahuluan yang terdiri dari penjelasan singkat tentang isi pelajaran, penjelasan isi relevansi isi pelajaran yang akan dipelajari dengan pengalaman mahasiswa, dan penjelasan tentang tujuan instruksional khusus, (b) komponen penyajian yang terdiri dari uraian, contoh, dan latihan, dan (c) komponen penutup yang terdiri dari tes formatif dan umpan balik serta tindak lanjut. Sebagian besar kegiatan instruksional dalam bahan instruksional berupa buku teks hanya memuat satu komponen, yaitu komponen penyajian berupa uraian isi pelajaran tanpa contoh dan latihan. Komponen pendahuluan dan komponen penutup jarang ditemukan dalam buku teks. 
Di samping itu, urutan penyajian isi pelajaran perlu disusun dari yang paling mudah ke yang paling sulit. Dengan memperhatikan aspek ini diharapkan mahasiswa dapat mempelajari isi pelajaran secara sistematis. Tidak melompat dari suatu bagian ke bagian yang lain. Hal ini jarang diperhatikan dalam penyusunan buku teks.

Latihan merupakan kegiatan belajar mahasiswa dalam rangka menerapkan apa yang sedang dipelajarinya. Dengan adanya latihan diharapkan mahasiswa dapat belajar dengan aktif yang akan mempercepat proses penguasaan terhadap isi pelajaran yang sedang dipelajarinya. Tanpa adanya latihan, mahasiswa tidak memiliki kesempatan untuk mengetahui apakah mereka telah menguasai isi pelajaran yang baru saja dipelajarinya. Hal ini pun jarang diperhatikan dalam penyusunan buku teks.

Untuk meyakini bahwa apa yang baru saja dipelajarinya telah benar, bahan instruksional Mandiri harus menyajikan jawaban yang jelas yang dapat digunakan sendiri oleh mahasiswa untuk mengecek jawabannya atas latihan yang dilakukannya. Jawaban ini dapat digunakan oleh mahasiswa untuk memperbaiki kesalahan yang mereka lakukan.

Dalam bahan instruksional Mandiri, petunjuk bagi mahasiswa dibutuhkan mereka untuk dapat mengetahui apakah mereka sudah dapat berpindah dari suatu kegiatan belajar ke kegiatan belajar selanjutnya atau perlu mengulang kembali ke kegiatan belajar sebelumnya. Bila mahasiswa sudah berhasil menjawab dengan benar latihan yang diberikan, mereka dapat melanjutkan ke kegiatan selanjutnya. Sebaliknya bila belum, mahasiswa perlu kembali ke kegiatan sebelumnya. Petunjuk seperti ini jarang ditemukan di dalam buku teks.

Namun demikian perlu dikemukakan pula bahwa kendatipun bahan instruksional Mandiri akan memberikan hasil belajar yang lebih baik dibandingkan dengan bahan instruksional PBS, bukan berarti bahan instruksional PBS tidak dapat digunakan sama sekali. Bila dalam keadaan tertentu dosen mempunyai kendala sehingga tidak dapat diperoleh bahan instruksional Mandiri, bahan instruksional PBS masih dapat digunakan dengan memperhatikan beberapa aspek. Aspek-aspek tersebut antara lain (a) kompilasi bahan disusun dalam suatu paket sehingga tidak menyulitkan mahasiswa dalam mencari dan menggunakannya, (b) urutan penyajian disusun dari yang paling mudah ke yang paling sulit dan dikemukakan pula keterkaitan antara satu bab dengan bab lainnya, diberikan latihan dalam bentuk tugas, (c) tugas-tugas yang dikerjakan mahasiswa dikoreksi dan diberi umpan balik agar mahasiswa mengetahui bahwa apa yang baru saja dipelajarinya sudah benar, dan (d) memberikan tindak lanjut berupa perintah untuk mempelajari kembali bila terdapat bagian-bagian yang belum dikuasainya.

Berdasarkan kesimpulan dan implikasi penelitian yang sudah dikemukakan di atas, disarankan agar dalam mengajar Pendidikan Agama Islam, dosen perlu menggunakan bahan instruksional Mandiri yang dikembangkan secara khusus. Uraian, contoh, dan latihan yang dirancang sesuai dengan karakteristik umum mahasiswa akan sangat membantu mereka di dalam memahami norma-norma agama yang diajarkan dalam Pendidikan Agama Islam secara efektif dan efisien.

\section{Ucapan Terima Kasih}

Terima kasih kepada Dekan Fakultas Ilmu Sosial dan Politik (FISIP) dan Dekan Fakultas Ilmu Pendidikan (FIP) Universitas Muhammadiyah Jakarta yang telah mendukung penelitian ini. 


\section{REFERENSI}

Akhadiah Maryono Kabirin, Sabarti. 1983. Pengaruh Materi Pengajaran Bahasa Indonesia, Lokasi Sekolah, dan Jenis Kelamin terhadap Kemampuan Penalaran Ilmiah Siswa SMP. Disertasi. Jakarta: FPS IKIP Jakarta.

Alan Januszewski dan Michael Molenda. 2008. Educational Technology. New York: Lawrence Erlbaum Associates.

Banathy. Bela H. 1968. Instructional Systems. Belmont, California : Fearon Publishers, Inc.

Bartel, Carl R. 1976. Instructional Analysis and Materials Development. Illinois: American Technical Publishers, Inc.

Bloom, Benjamin S et al. 1965. Lihat W. Robert Houston, et al., Touch the future, Teach! 1988. St Paul: West Publishing Company.

Bower, Gordon M. and Hilgard, Ernest R. 1986. Theories of Learning. Fourth Edition. Englewood Cliffs, New Jersey: Prentice Hall, Inc.

Chris Watkins et al, 2007. Effective Learning in Classrooms. London: Sage Publications.

Dick, Walter and Carey, Lou. 2009. The Systematic Design of Instruction. New Jersey: Pearson.

Gagne, Robert M. 2005. Principles of Instructional Design. Belmont, CA: Wadsworth/Thomson Learning.

E. Kemp, Jerrold. 1977. Instructional Design. California: Fearon Publisher.
Hidayat, Anwar. 2016. Pengertian Data Outlier Univariat dan Multivariat. https://www.statistikian.com/2014/04/indepe nden-t-test-dengan-spss.html. Diakses pada Senin, 4 Maret 2019.

Isaac, Stephen and Michael, William B. 1982. Handbook in Research and Evaluation. California: Edits Publisher.

Je Dae Sik. 1996. Pengembangan Materi Pelajaran Bahasa Indonesia untuk Para Manajer Korea di Jakarta. Disertasi. Jakarta: PPS IKIP Jakarta.

Lefrancois, Gay R. 1995. Theories of Human Learning. California: Brooks/Cole Publicing Company.

Nasution, Harun. 1995. "Perlunya Menghidupkan Kembali Moral" dalam Harun Nasution (ed). Pendidikan Agama Dalam Perspektif Agama-Agama. Jakarta: Konsorsium Pendidikan Agama di Perguruan Tinggi Umum. DitJen Dikti.

Noah P. Barsky, et al, 2008. The Power of Technology for Learning. New York: Springer.

Riberu. 1995. "Membentuk Filsafat Hidup Pribadi" dalam Harun Nasution (ed). Pendidikan Agama Dalam Perspektif Agama-Agama. Jakarta: Konsorsium Pendidikan Agama di Perguruan Tinggi Umum. DitJen Dikti.

Rifqiyati dkk. 1994. Pengaruh Hasti Belajar AI-lslam dan Sikap Terhadap Peraturan Kampus Pada Peritaku Islami Mahasiswa. Laporan Penelitian. Jakarta: Universitas Muhammadiyah Jakarta.

Rita C. Richey, James D. Klein, Monica W. Tracey. 2011. The Instructional Design Knowledge Base: Theory, Research, and Practice. New York: Routledge. 
Romiszowki, AJ. 1981. Designing Instructional System. London: Kogan Page.

Suparman, Atwi. 2012. Desain instruksional. Jakarta: PAU PPA.

Suradika, Agus dan Sri Mulyani. 1997. Pengajaran Agama di Perguruan Tinggi Umum. Jurnal Penelitian No.Vll TH.1ll. Universitas Muhammadiyah Jakarta.

Smaldino, Sharon E., Rusell, James D., Heinich, Robert, Molenda, Michael. 2005. Instructional Technology and Media for Learning. Eight Edition. New Jersey: Pearson.
Trochim, William M.K. 2020. Research Methods Knowledge Base. https://socialresearchmethods.net/kb/twogroup-experimental-designs/, diakses pada senin, 30 Maret 2019, pukul 18.30).

Widodo, Antonius Tri. 1993. Tingkat Keterbacaan Teks: Suatu Evaluasi Terhadap Buku Teks llmu Kimia Kelas Satu Sekolah Menengah Atas, Disertasi. Jakarta: PPS IKIP Jakarta. 